\title{
Current Research in
}

\section{Bioorganic \& Organic Chemistry}

\section{Toxicity Study of Confiscated Illicit Opium and Heroin on Liver}

\author{
Farid A. Badria", Mona El-Neketi, Hassan-Elrady A. Saad \\ Department of Pharmacognosy, Mansoura University, Egypt
}

"Corresponding author: Farid A. Badria, Department of Pharmacognosy, Mansoura University, Mansoura 35516, Egypt. Tel: +201001762927; Email: faridbadria@gmail.com

Citation: Badria FA, El-Neketi M, Saad Hassan-Elrady A (2018) Toxicity Study of Confiscated Illicit Opium and Heroin on Liver. Curr Res Bioorg Org Chem: CRBOC-104. DOI: 10.29011/CRBOC-104. 100004

Received Date: 17 February, 2018; Accepted Date: 27 February, 2018; Published Date: 05 March, 2018

\begin{abstract}
The Impact Effect of common narcotic drugs (Heroin \& Opium), in comparison with experimentally proven hepatotoxic agents (Carbon Tetrachloride (CCl4), on liver of mice was assessed. Histopathological investigations of the liver sections of revealed abnormalities of the liver tissues (extensive infiltration of hepatocytes and inflammation of portal tract, dilated blood sinusoids with connective tissue proliferation in the portal areas, wide areas of hepatocellular necrosis, and preportal fibrotic formation with thick septa) indicating liver hepatotoxicity. Illegally sold opium samples is usually adulterated and contaminated with high level of arsenic and lead that may be associated with liver diseases, so the level of arsenic and lead in illicit opium and heroin samples was determined using atomic absorption method. This is an attempt to define the incidence and severity of liver disorders among a large number of drug addicts. The concentration of arsenic and lead were found to be high in illicit opium and heroin samples. In conclusion: The hepatotoxicity caused by the administration of the common narcotic drugs (illicit opium and heroin samples) may be partially due to excessive cumulative doses of illicit narcotic drugs, and/or the presence of heavy metals (arsenic and lead).
\end{abstract}

Keywords: Arsenic; Atomic Absorption; Carbon Tetrachloride; Hepatotoxic Agents; Histopathological Investigation; Heroin; Narcotic drugs, Lead; Liver Cell Damage; Opium

\section{Introduction}

Acute and chronic liver diseases were reported among heroin addicts; laboratory evidence of hepatic dysfunction has been reported in up to $75 \%$ of parenteral heroin users. The cause has usually been related to viral hepatitis. Other factors, such as the effect of heroin adulterant mixtures and multiple drug abuse upon the liver tissues have also been implicated. In contrast, little attempt is given to define the incidence and severity of liver abnormalities in a large group of non-parenteral drug abuse [1], so the impact of illicit opium and heroin samples, in comparison with experimentally proven hepatotoxic agent $\left(\mathrm{CCl}_{4}\right)$ on the liver of mice was assessed. Cases with acute lead poisoning due to contaminated opium were reported. The predominant features of most cases were: hepatic failure, reversible acute tubular necrosis, severe neuropathy and respiratory paralysis. Chelation therapy resulted in a fall in blood lead to within normal limits [2-4].
Illegally sold opium is usually adulterated with high level of arsenic. This adulteration was supposed to enhance the aphrodiasic properties of opium. Some patients, who are opium addicts, may have a clinical picture of arsenical neuropathy and hepatomegaly. Elevated levels of arsenic may be associated with liver disease. Microscopic examination of liver tissues revealed periportal fibrosis. The opium obtained from the Indian source revealed to have an exceptionally high arsenic content $(25 \mathrm{mg} / 100 \mathrm{gm})$ [5-9]. Therefore, the level of lead and arsenic were measured in the confiscated opium and heroin samples.

\section{Experimental}

\section{Materials and Reagents}

Drugs

- A Confiscated heroin sample: It was obtained from seizure number 978/1988, Suez- Egypt. It was formed of cylindrical pieces with rounded ends, $20 \mathrm{~cm} \mathrm{~L}$ and $4 \mathrm{~cm} \mathrm{D}$. Each piece was wrapped externally with green adhesive tape, $1.5 \mathrm{~cm} \mathrm{~W}$, and internally another wrapping of yellowish-white to light brown paper. After the removal of wrapping, heroin was found 
in the form of small hard granular pieces, grayish-brown to dark brown to nearly blackish in color, measuring about 0.5 $1.5 \mathrm{~cm} \mathrm{D}$ and having intense vinegar like odor. Grinding of heroin pieces produces a light brown to dark brown powder with repulsive vinegar-like odor.

- B Confiscated opium sample: It was obtained from seizure number 422/1991, Ataka, Suez-Egypt. It occurred in the form of large rectangular blocks wrapped in yellowish-white papers, measuring about $15 \mathrm{~cm} \mathrm{~L}, 10 \mathrm{~cm} \mathrm{~W}$ and $10 \mathrm{~cm} \mathrm{H}$. After removing of the wrapping the blocks appeared black in color and having a strong characteristic narcotic odor. From one of the opium blocks a piece of $50 \mathrm{gm}$ was removed and powdered in a glass mortar to produce a dark brown to nearly black powder.

Chemicals: All chemicals and solvents are of analytical grade and purchased from Adwik, Egypt.

Reagents: Histopathological reagents: Hematoxylin and Eosin (Hx and E), Phosphotungstic Acid Hematoxylin (PTAH) and Masson, S Trichrome (MT) stains.

Apparatus: Microtome (Leica R M 2025, Nussloch); Digital camera Olympus 2020 fitted with C mount (Olympus company, Japan); Atomic Absorption spectrophotometer, Varian SpectrAA 220, with air-acetylene flame for lead and graphite for arsenic at National Research Center, Dokki, Cairo, Egypt.

Experimental animals: Male albino mice (local bread, 20-25 gm), were purchased from Theodor Billharze Institute, Cairo, Egypt.

\section{General Procedure}

\section{Histopathological investigation}

\section{1-Animal grouping}

Fifty mice were divided into ten groups (five mice each).

Group 1 (control): Injection of $200 \mu 1$ normal saline I.P 3 doses / 3 days' intervals.

Group 2-5: Injection of $5 \mathrm{mg} / \mathrm{ml}$ fresh opium in saline solution I.P 3 doses / 3 days' intervals in a dose equals to $25,50,75$ and 100 $\mathrm{mg} / \mathrm{kg}$ body weight.

Group 6-9: Injection of $5 \mathrm{mg} / \mathrm{ml}$ fresh heroin in saline solution I.P 3 doses / 3 days' intervals in a dose equals to $25,50,75$ and 100 $\mathrm{mg} / \mathrm{kg}$ body weight.
Group 10: Injection of a fresh mixture of $\mathrm{CCl}_{4}$ and corn oil (equal volumes) I.P. 3 doses / 3 days' intervals in a dose equals to $2 \mathrm{ml} /$ $\mathrm{kg}$ body weight.

\section{2- Samples Collection}

All these animal groups were under experiment for 10 days. Animals were scarified by cervical dislocation, $24 \mathrm{hr}$ after the last dose, livers were immediately excised, fixed in $10 \%$ neutral buffered formalin $\mathrm{pH} 7.4$, dehydrated in an ascending grades of absolute ethyl alcohol. Cleared in xylene and then embedded in paraffin wax and sectioned to $4 \mu \mathrm{m}$ thickness. For histopathological studies, sections were stained with Hematoxylin and Eosin ( $\mathrm{Hx}$ and E). For histochemical studies, sections were stained with Phosphotungistic acid hematoxylin and Masson's trichrome. All sections were examined by light microscope (x 10) to examine the histopathological changes.

\section{Determination of Arsenic and lead in Illicit Opium and Heroin Samples}

Sample preparation

Illicit opium and heroin stock solutions were prepared at conc. 5 $\mathrm{mg} / \mathrm{ml}$ distilled water.

Determination of arsenic and lead

The level of arsenic and lead in illicit opium and heroin samples was determined using atomic absorption method.

\section{Results and Discussion}

\section{Results}

\section{Histopathological Investigation}

Histopathological examination of liver tissues revealed paracentral inflammation and diffused fatty changes. Staining with hematoxylin and Eosin showed extensive infiltration of hepatocytes and inflammation of portal tract and dilated blood sinusoids (Figure 1). Staining with Phosphotungistic acid hematoxylin, showed Prefibrotic changes due to excessive changes of $\mathrm{CCl}$ and / or illicit samples and mild dilation of central vein (Figure 2). Staining with Masson' s trichrome (Figure 3), showed: Collagen fiber around the wall of central vein, hepatic artery, Portal vein and bile duct of portal tract. Collagen fiber in interstitial spaces. Progressive preportal fibrosis. Mild dilation of central vein. 


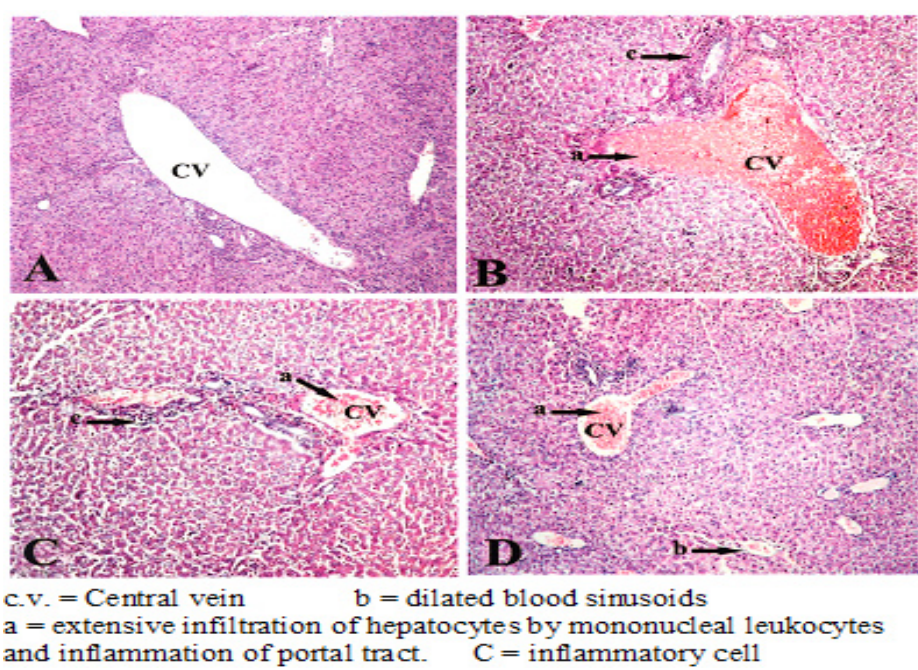

Figure 1: Photomicrograph of liver of control mice (A), those received heroin (B), opium (C), and $\mathrm{CCL}_{4}$ (D) stained with $\mathrm{Hx} \& \mathrm{E}$, x10.

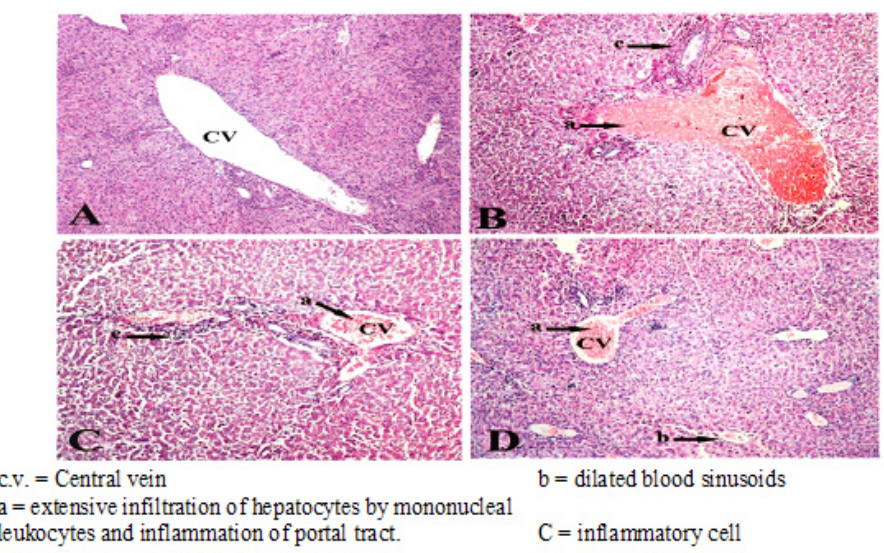

Figure 2: Photomicrograph of liver of control mice (A), those received heroin (B), opium (C), and CCL4 (D) stained with (Phosphotungestic acid heamatoxylin stain, $\mathrm{x} 10)$.
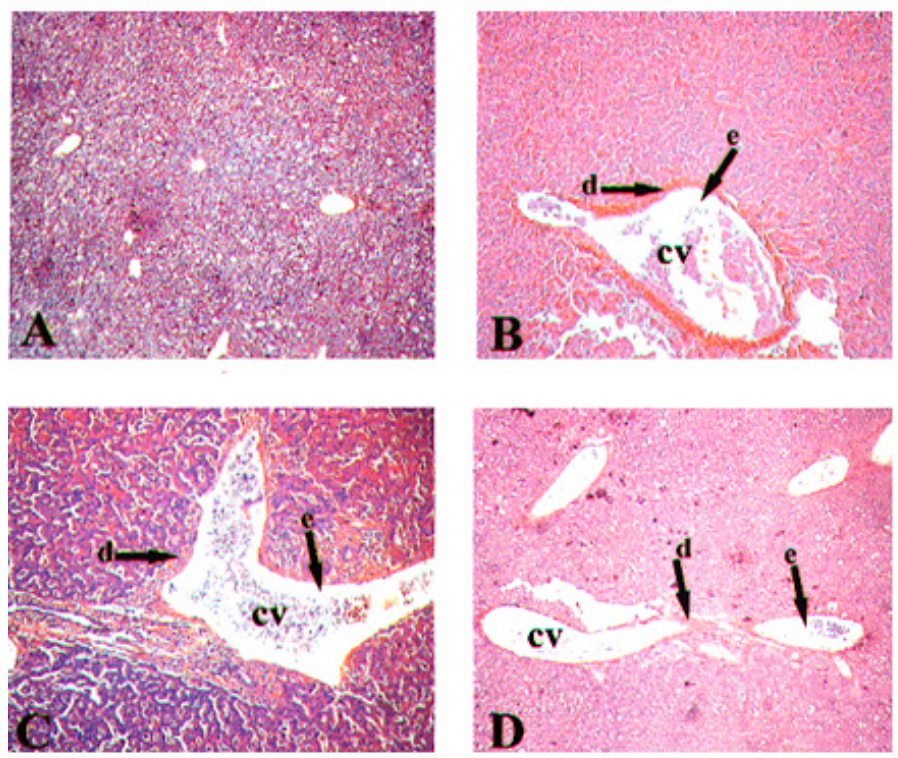

c.v. $=$ Central vein, $e=$ mild dilation of central vein, $d=$ Prefibrotic changes due to excessive changes of CCL4 and / or illicit samples

Figure 3: Photomicrograph of liver of control mice (A), those received heroin (B), opium (C), and $\mathrm{CCL}_{4}$ (D) stained with Masson's trichrome stain, $\mathrm{x} 10)$.

\subsubsection{Determination of Lead and Arsenic}

The level of lead and arsenic in illicit opium and heroin samples is shown in (Table 1).

\begin{tabular}{|c|c|c|}
\hline Metal & Illicit opium sample & Illicit heroin sample \\
\hline Arsenic & $\begin{array}{c}143.6 \mathrm{mg} / 100 \mathrm{gm} \text { illicit } \\
\text { opium sample }\end{array}$ & $\begin{array}{c}\mathbf{8 8 . 4} \mathrm{mg} / 100 \mathrm{gm} \text { illicit } \\
\text { heroin sample }\end{array}$ \\
\hline Lead & $\begin{array}{c}130 \mathrm{mg} / 100 \mathrm{gm} \text { illicit } \\
\text { opium sample }\end{array}$ & $\begin{array}{c}128 \mathrm{mg} / 100 \mathrm{gm} \text { illicit } \\
\text { heroin sample }\end{array}$ \\
\hline
\end{tabular}

Table 1: Determination of lead and arsenic on illicit opium and heroin samples using atomic absorption method. 
Citation: Badria FA, El-Neketi M, Saad Hassan-Elrady A (2018) Toxicity Study of Confiscated Illicit Opium and Heroin on Liver. Curr Res Bioorg Org Chem: CRBOC104. DOI: $10.29011 /$ CRBOC-104. 100004

\section{Discussion}

\section{Histopathological investigation}

Carbon tetrachloride induced hepatotoxicity has been widely used as an animal model to study liver injury. $\mathrm{CCl}$ is bio transformed by cytochrome P-450 in the hepatic microsomal oxidase system to trichloromethyl free radicals $[10,11]$. The reactive $\mathrm{CCl}_{3}$ radicals bind to unsaturated fatty acids in the cytoplasmic membrane and induce lipid-peroxidation. This may alter intracellular calcium homeostats is or impair protein biosynthesis and finally cause cell death [11-14]. The histopathological abnormalities of the liver tissues (pericentral inflammation, acute inflammatory changes with connective tissue proliferation in the portal areas, diffused fatty change, wide areas of hepatocellular necrosis, and pseudolobular fibrotic formation with thick septa) in opium and heroin treated groups proved their hepatotoxicity. These results are in agreements with the reported hepatotoxicity of opium and heroin which starts from chronic hepatitis to fibrosis, necrosis and finally liver failure $[15,16]$.

\section{Determination of lead and Arsenic}

\section{A- Arsenic}

Opium obtained from government sources had 0 to $18.2 \mu \mathrm{g}$ of arsenic per $100 \mathrm{gm}$ of opium [6]. The high arsenic content of illicit opium $(143.6 \mathrm{mg} / 100 \mathrm{gm})$ sample and illicit heroin (88.4 $\mathrm{mg} / 100 \mathrm{gm}$ ) sample confirms that the provided illicit opium sample is adulterated with arsenic. The use of arsenic can affect the liver adversely and has been well documented as an etiologic agent for the development of cirrhosis and idiopathic portal hypertension. Available information reveals that the so called opium manufacturers adulterate it with arsenic in varying quantity for two reasons; firstly, it is believed to be a general tonic and secondly it is said to be an aphrodisiac, which, when combined with opium - enhances the aphrodisiac quality of opium. So opium or heroin addicts will have a clinical picture of arsenical neuropathy and hepatomegaly [6].

\section{B- Lead}

The concentrations of lead in various food items are highly variable. Several studies have reported average lead intakes in the range of 100-500 $\mu \mathrm{g} /$ day for adults, with individual diets covering a much greater range. More recent data indicates total daily intakes of about $100 \mu \mathrm{g}$ or less [17], $1000 \mu \mathrm{g} / \mathrm{g}$ lead in soil or dust [18] and $1.25 \mu \mathrm{g} / \mathrm{g}$ food [19] may cause lead toxicity. So $130 \mathrm{mg} / 100$ gm illicit opium sample and $128 \mathrm{mg} / 100$ gm illicit heroin sample will have considered to be a high level of lead, leading to lead toxicity. Lead-induced health effects in adults [20] The toxicity of lead may largely be explained by its interference with different enzyme systems: lead inactivates these enzymes by binding to SH-groups of its proteins or by displacing other essential metal ions. For this reason, many organs or organ systems are potential targets for lead, and a wide range of biological effects of lead have been documented. These include effects on haem biosynthesis, the nervous system, the kidneys and reproduction, and also cardiovascular, hepatic, endocrinal and gastrointestinal effects.

1. -Effects on the nervous system may lead to encephalopathic signs and symptoms, peripheral nerve dysfunction (slowed nerve conduction velocities).

2. - Effects on haem synthesis lead to anemia.

3. -Effects on kidney function develop nephrotoxicity.

4. -Effects on blood pressure causes a two-fold increase in blood lead was associated with a 1-mmHg increase in systolic and a $0.7-\mathrm{mmHg}$ increase in diastolic blood pressure.

\section{Conclusion}

The hepatotoxicity caused by the administration of the common narcotic drugs (illicit opium and heroin samples) may be partially due to excessive cumulative doses of illicit narcotic drugs, foreign matters and the presence of heavy metals (arsenic and lead).

This study may help in shedding more lights on the causes of acute and chronic liver diseases among heroin addicts. Our laboratory evidences of hepatic dysfunction have been reported in this study. Moreover, we had documented other factors, such as the effect of heroin adulterant mixtures and multiple drug abuse upon the liver tissues. Therefore, the impact of illicit opium and heroin samples, in comparison with experimentally proven hepatotoxic agent $\left(\mathrm{CCl}_{4}\right)$ on the liver of mice was assessed.

\section{References}

1. Stimmel B, Vernace S, Tobias H (1972) Hepatic dysfunction in heroin addicts: the role of alcohol. J Am Med Assoc 222: 811-812.

2. Chia BL, Leng CK, Hsii FP, Yap MH, Lee YK (1973) Lead poisoning from contaminated opium. Br Med J 1: 354

3. Beattie AD, Briggs JD, Canavan JS, Doyle D, Mullin PJ, et al. (1975) Acute lead poisoning: Five cases resulting from self-injection of lead and opium. Q J Med 44: 275-284.

4. Beattie AD, Mullin PJ, Baxter RH, Moore MR (1979) Acute lead poisoning: an unusual cause of hepatitis. Scott Med J 24: 318-321.

5. Eaton RD (1977) Arsenic in opium. Lancet 1: 903-904.

6. Datta DV, Kaul MK (1977) Arsenic adulteration in opium (ARSENICOSIS-Areal danger to heatlh in developing countries). Bull Narc 29:41-44.

7. Datta DV, Mitra SK, Chhuttani PN, Chakravarti RN (1979) Chronic oral arsenic intoxication as a possible aetiological factor in idiopathic portal hypertension (non-cirrhotic portal fibrosis) in India. Gut 20: 378-384.

8. Narang AP (1987) Arsenicosis in India. J Toxicol Clin Toxicol 25: 287295. 
Citation: Badria FA, El-Neketi M, Saad Hassan-Elrady A (2018) Toxicity Study of Confiscated Illicit Opium and Heroin on Liver. Curr Res Bioorg Org Chem: CRBOC104. DOI: $10.29011 /$ CRBOC-104. 100004

9. Narang AP, Chawla LS, Khurana SB (1987) Levels of arsenic in Indian opium eaters. Drug Alcohol Depend 20: 149-153.

10. Noguchi T, Fong KL, Lai EK, Alexander SS, King MM, et al. (1982) Specificity of a phenobarbitol-induced cytochrome P-450 for metabolism of carbon tetrachloride to the trichloromethyl radical. Biochem Pharmacol 31: 615-624.

11. Farber JL, Gerson RJ (1984) Mechanisms of cell injury with hepatotoxic chemicals. Pharmacol. Rev 36: 71s-75s.

12. Clawson GA (1989) Mechanism of carbon tetrachloride hepatotoxicity. Pathol Immunopath Res 8: 104-112.

13. Recknagel RO, Glende EA Jr, Dolak JA, Waller RL (1989) Mechanisms of carbon tetrachloride toxicity. Pharmacol Ther 43: 139-154.

14. 14.Williams AT, Burk RF (1990) Carbon tetrachloride hepatotoxcicity: an example of free radical-mediated injury. Seminars in liver disease 10: $279-284$.
15. Louria DB, Hensle T, Rose J (1967) The major medical complications of heroin addiction. Ann Inter Med 67: 1-22.

16. Ellenhorn MJ, Bareclox DG (1988) Medical toxicology, Diagnosis and treatment of human poisoning. New York Elsevier 698-709.

17. The Hague (1984) Guidelines for lead, Recommended standards for outdoor air quality. Ministry of Health and Environmental Hygiene.

18. Tong S, von Schirnding YE, Prapamontol (2000) Environmental lead exposure: a public health problem of global dimensions. Bulletin of the World Health Organization 78: 1068-1077.

19. Rahbar MH, White F, Agboatwalla M, Hozhabri S, Luby S (2002) Factors associated with elevated blood lead concentrations in children in Karachi, Pakistan. Bulletin of the World Health Organization 80: 769-775.

20. WHO Regional Office for Europe, Copenhagen, Denmark, 2001, Chapter 6.7 Lead, Air Quality Guidelines - Second Edition. 